Winter 2016

\title{
One Pillar: Legal Authority and a Social License to Operate in a Global Context
}

Hans Lindahl

Tilburg University, lindahl@uvt.nl

Follow this and additional works at: https://www.repository.law.indiana.edu/ijgls

Part of the Comparative and Foreign Law Commons, Human Rights Law Commons, and the International Law Commons

\section{Recommended Citation}

Lindahl, Hans (2016) "One Pillar: Legal Authority and a Social License to Operate in a Global Context," Indiana Journal of Global Legal Studies: Vol. 23 : Iss. 1 , Article 9.

Available at: https://www.repository.law.indiana.edu/ijgls/vol23/iss1/9

This Article is brought to you for free and open access by the Law School Journals at Digital Repository @ Maurer Law. It has been accepted for inclusion in Indiana Journal of Global Legal Studies by an authorized editor of Digital Repository@Maurer Law. For more information, please contactrvaughan@indiana.edu.

\section{$\Psi$}

JEROME HALL LAW LIBRARY

INDIANA UNIVERSITY

Maurer School of Law
Bloomington 


\title{
One Pillar: Legal Authority and a Social License to Operate in a Global Context
}

\author{
HANS LINDAHL*
}

\begin{abstract}
The claim that businesses have a social license to operate acquires concrete form in the second pillar of the U.N. Guiding Principles on Business and Human Rights (UNGPs) in the fundamental distinction between "compliance with all applicable laws" and "respect for human rights." The aim of this paper is to critically examine the presuppositions that undergird this distinction and to explain how and why moving beyond state-centered thinking about law, in response to violations of human rights by globally operating businesses, requires acknowledging that there is one pillar that embraces states and businesses: the legal obligation to comply with international human rights law. Arguing that legal order can best be conceptualized as authoritative collective action, the paper develops the one-pillar thesis along two fronts. The first argues that there can be no credible social license to operate in a global context absent authorities that uphold and regulate joint action as regards what is to count as a global collective's bounded common good and as its bounded common place. Yet, it is this authoritative dimension of a social license to operate that the UNGPs preclude by proclaiming that the corporate responsibility to respect human rights does not itself create a legal obligation. The second argues that both states and globally operating businesses are legal orders in their own right. From the firstperson plural perspective of authoritatively mediated collective action, nothing justifies separating a state's obligation to uphold human rights, as per the first pillar of the UNGPs, from a business's responsibility to respect human rights, as per the second pillar.
\end{abstract}

* Professor of Legal Philosophy, Tilburg University, Tilburg, Netherlands. Research Fellow, Stellenbosch Institute for Advanced Study, Mostertsdrift, Stellenbosch, South Africa.

Indiana Journal of Global Legal Studies Vol. $23 \# 1$ (Winter 2016)

(c) Indiana University Maurer School of Law 


\section{INTRODUCTION}

The opening statement of the United Nations Guiding Principles on Business and Human Rights (UNGPs) indicates that "business enterprises [are] specialized organs of society performing specialized functions." 1 It is no exaggeration to suggest that the key challenge confronting the UNGPs - even the central problem summarized by the expression "business and human rights"-is enclosed in this seemingly straightforward expression. How does one make sense of, and lend traction to, the preposition "of" in the term "specialized organs of society"? At stake is not merely an abstract relation of dependency between society and businesses; the commentary to the second pillar of the UNGPs spells out the meaning of this preposition when averring that businesses are to have a "social license to operate." In other words, at issue is nothing less than the authorization of businesses and their operations, such that society can view businesses as its own organs and their functions and activities as its own functions and activities.

I argue in this paper that the key to this question lies in the connection between the two distinctions that have been the unquestioned presupposition of a social license to operate in the framework of what might be called "territorial human rights government": the public/private and inside/outside distinctions. Indeed, economic globalization has put pressure on both distinctions and on their connection as a result of the privatization and marketization of public authority and the enormous growth of cross-border activities, which increasingly elude the de jure and de facto control of states. The moniker "global human rights governance" suggests that the conceptual and institutional challenge confronting a theory of authority in a global context is to reconstruct the notion of publicness in a global context in a way that need not rely on the inside/outside distinction. Indeed, general wisdom has it that a credible social license to operate in the context of economic globalization requires the emergence of institutions that can articulate a global public good that is no longer spatially bounded. Despite its apparent novelty, this assumption actually entrenches a thoroughly state-centered understanding of the inside/outside distinction. While endorsing the thesis that a social license to operate in a global context requires the emergence of institutionally mediated representations of the global public good, the paper also holds that there can be no such good-hence no credible social license to operate in a global context-absent a spatial closure whereby global society closes

1. U.N. Human Rights Office of the High Commissioner, Guiding Principles on Business and Human Rights 1, HR/PUB/11/04 (2011). 
itself into an inside vis-à-vis an outside. The relation between authority and place is necessary, not contingent. Contrasting the UNGPs to the Guidelines for Multinational Enterprises of the Organisation for Economic Co-operation and Development (OECD), the paper argues, in conclusion, that the real question raised by "global human rights governance" is not how to move beyond the inside/outside distinction in the face of cross-border activity but rather how to conceptualize and institutionalize the connection between these two distinctions in a global context, such that businesses, multinational corporations in particular, are under a legal duty to comply with human rights law.

\section{Global Challenges to Territorial Human Rights Government}

The claim that businesses are to have a social license to operate acquires concrete form in the second pillar of the UNGPs in the fundamental distinction between compliance with all applicable laws and respect for human rights. ${ }^{2}$ As the UNGPs make abundantly clear, the latter does not create a legal obligation, nor does it in principle give victims of human rights abuses by business enterprises legal standing to demand redress for such breaches. ${ }^{3}$ To the extent that there is a legal obligation to respect human rights, and to the extent that such obligations give rise to legal remedies, businesses and their operations fall squarely within the first term of the distinction: compliance with all applicable laws. This is not to say that the demand that businesses respect human rights is without any "force"; it is to say that its force is the force of "social expectations" and the consequences that might ensue when such expectations are disappointed.

At one level, this distinction means that human rights can function either as legal or as social norms, a typology that was already well established in the heyday of territorial government. ${ }^{4}$ At a deeper level, however, the distinction reflects the profound transformation that has taken place in the passage from what scholars dub "territorial government" to "global governance."5 In fact, the very idea that businesses require a "social"-rather than a state-license to operate

2. Id. at 13 .

3. The General Principles of the UNGPs note, amongst others, that "[n]othing in these Guiding Principles should be read as creating new international law obligations, or as limiting or undermining any legal obligations a State may have undertaken or be subject to under international law with regard to human rights." Id. at 1.

4. For a good survey of theories of social norms, see Cristina Bicchieri and Ryan Muldoon, Social Norms, STAN. ENCYCLOPEDIA OF PHIL., http:/plato.stanford.edu/entries/ social-norms/ (last updated Mar. 20, 2014).

5. See James N. Rosenau \& ERnst-Otto Czempiel, Governance Without GovernMENT: ORDER AND CHANGE IN WORLD POLITICS 272 (1992). 
precisely captures the nature of the transformation and the difficulties it calls forth. To put it crudely, whereas "compliance with all applicable laws" signals the extent to which businesses and their operations continue to fall within the orbit of territorial government, "respect for human rights" is a specific interpretation of what it means that businesses and their operations now also fall under the aegis of global governance.

It is tempting to ask whether respect for human rights, as laid out in the second pillar of the UNGPs, is consistent with a credible sense of a social license to operate. But I will postpone dealing with this question. For the fundamental question we must address first is the concept of law that would be appropriate to understand why businesses might-and should-be legally bound by human rights law in their global operations. In effect, it is of crucial importance to understand and critically probe the double distinction that governs the UNGPs in their entirety. Generally, the UNGPs distinguish between states and businesses, addressing the relation between states and human rights in the first pillar and the relation between businesses and human rights in the second. It is on the basis of this cardinal distinction that the UNGPs focus on businesses, distinguishing between their compliance with all applicable laws and respect for human rights. This twofold distinction, I argue, entrenches a state-centered concept of law in the very move by which it claims to move beyond it. Instead of taking this twofold distinction for granted, I reconsider what we mean by a legal obligation, linking it to certain structural features of legal orders of which state law is one exemplar but by no means the only one. To the extent that we can show that other configurations of these structural features are possible - and in fact are already emerging -in a global context, we can begin to imagine the kinds of transformations of legal authority that would be required for a legal license to operate on a global scale, if one assumes, as I do, that the emergence of something like a global state is not in the cards.

To prepare the way for developing a concept of legal order that connects what the UNGPs disconnect-state and business; compliance with law and respect for human rights-I begin by examining the presuppositions that govern the current debate about legal authority in a global context. Indeed, there is wide-ranging agreement among sociologists that economic globalization marks the crisis of two distinctions that have structured the exercise of authority in territorial government. The first is the public/private divide. We are witness to the far-ranging privatization and marketization of functions that have 
previously been the remit of state authority. ${ }^{6}$ Private actors and market mechanisms increasingly operate as the vehicles for social ordering, to the detriment of state regulation. In particular, the notion of a common or public good has come under increasing pressure to the extent that both private actors and market mechanisms systematically tend to favor particular interests. ${ }^{7}$ Hans Kelsen's reminder of the ideological character of the distinction between public and private law seems particularly apposite: "[r]epresenting as absolute the opposition between private and public law ... creates the illusion that the field of public law alone ... is the domain of political power, which is totally excluded from the [domain] of private law," a domain usually portrayed as neutral. ${ }^{8}$ Against the neutralization and depoliticization of private law and private self-regulation, Kelsen reminds us that subjective rights are no less political rights than civil and political rights conventionally understood. Kelsen adds that

[to] distinguish in principle between a private nonpolitical sphere of the law and a public political sphere is to obscure the fact that the 'private' law created in the contract is no less the arena of political power than the public law created in legislation and administration. What we call private law . . . is simply a particular form of law, the form corresponding to the capitalistic economic system of production and distribution; its function, then, is the eminently political function of exercising power. ${ }^{9}$

What gets endangered or even lost in the notion of private selfregulation is the reference to commonality or publicness concealed in the "self" of self-regulation. Indeed, the identity at stake in self-

6. See generally SASKIA SASSEN, LOSING CONTROL? Sovereignty IN AN AGE OF GLOBALIZATION (1996) (examining the rise of private transnational legal codes and supranational institutions within the global economy); SASKIA SASSEN, TERRITORY, AUthority, Rights: From MEdieval to Global AsSEMBlages (2006) (discussing globalization in terms of the institutions originally developed for nations but that are now contributing to the denationalization of those institutions).

7. See A. Claire Cutler, Private Power and Global Authority: Transnational Merchant LaW in the Global Political Economy 1 (Steve Smith et al. eds., 2003) ("Today, forces of globalization and privatization are relocating the boundary between private and public authority in international commercial relations and creating new opportunities for private, corporate actors to exercise power and influence.").

8. Hans Kelsen, Introduction to the Problems of Legal Theory 95 (Bonnie Litschewski Paulson \& Stanley L. Paulson trans., 1992) (1934).

9. Id. at $95-96$. 
regulation does not simply mean that the subjects of lawmaking are the same as the addressees thereof. ${ }^{10}$ This would amount to collapsing identity as selfhood (ipse) into identity as sameness (idem). ${ }^{11}$ The "self" of private self-regulation, no less than the "self" of collective self-rule in public lawmaking, refers to the reflexive relation whereby a manifold of actors view and refer to themselves as a group, the members of which jointly enact a norm in their shared interest. Christopher Kutz makes a similar point in critiquing the methodological individualism of social theories that reduce collective action to an aggregation of acts by individual agents, each of whom posits and pursues her interests independently of all others: "The self of self-government is a 'we', not an 'I."' 12 Accordingly, a claim to commonality, to publicness, is built into the notion of collective selfhood.

This insight makes a crucial contribution to a theory of authority and authorization in the framework of territorial government: if the reference to a common interest or good is the way in which a manifold of individuals view themselves as a social group, then "public" and "private" lawmaking are part and parcel of the single process by which the members of a state rule themselves. Collective self-rule under territorial government concerns the structure of lawmaking as such, not merely one of its forms, and encompasses what legal doctrine calls public and private law. What renders private self-regulation authoritative in territorial government is not, or not merely, that the private actors who enacted it are "the same" as its addressees; it is that the norms they enact can be viewed, however provisionally and defeasibly, as a concretization of the common good of the larger collective of which they are a part. This means that norms enacted by private actors can be viewed as the larger collective's own norms, as norms it has authorized, and their acts of lawmaking as authorized acts of lawmaking. ${ }^{13}$ It also means that acts of private actors can be viewed

10. See Hans Kelsen, The PURe Theory of LaW 280-81 (Max Knight trans., Univ. Cali. Press 2d rev. ed. 1967) (1934).

11. See PAUl Riceur, ONESELF AS ANOTher 2-3, 115-25 (Kathleen Blamely trans., Univ. Chicago Press 1992) (1990).

12. Christopher Kutz, The Collective Work of Citizenship, 8 LEGAL THEORY 471, 472 (2002).

13. The structure of authorization I envisage is clearly visible in Steven Schwarcz' useful parsing of rulemaking into four categories according to the level of government participation. They are divided as follows: (i) "rules originated and put into force by sovereign governments"; (ii) "rules originated by private actors but put into force by sovereign governments"; (iii) "rules originated and put into force by private actors pursuant to government delegation"; and (iv) "rules adopted by private actors without government sanction or enforcement." Steven L. Schwarcz, Private Ordering, 97 Nw. U. L. REV. 319, 324 (2002). While, in his view, only the last three are forms of private ordering, I would argue that, from the point of view of authorization, the first three are on a 
as the collective's own acts, to the extent that they are in accordance with-authorized by - the common good, as spelled out in human rights, among other doctrines. By these lights, the license to operate of businesses in the framework of territorial government is premised on the institutionalization of the insight that the distinction between the public and the private is itself public.

Here, a second distinction comes into play: the distinction between inside and outside. If the authorization of private actors and their acts depends on their conception as particular actualizations of the common good of the larger collective of which they are part, this reference to a larger collective presupposes a spatial closure absent which one could not identify the collective of which those actors and their acts partake. In territorial government, publicness, in the sense of a common good, is conditioned by a spatial closure, in the sense of a common space. Conversely, a common space, in the sense of territorial government, is conditioned by a common or public good. Extending a license to operate to businesses, which means authorizing their acts to the extent that they are in accordance with the common good, presupposes a closure that splits space into domestic and foreign places, and in that sense into an inside and an outside. Crucially, what is at stake in this closure of space into an inside is that it then becomes possible for state authorities to establish what ought and ought not to take place-literally-in the collective's common space. In other words, absent the closure of space into a unity of legal places, it would not be possible for territorial human rights government to draw the distinction between legal and illegal behavior, including behavior that is in conformity with or in breach of human rights obligations.

Economic globalization challenges this internal connection between the public/private and inside/outside distinctions, a connection that is implicit in the distinction between compliance with all applicable laws and respect for human rights. This distinction also illustrates the difficulties encountered by schemes of global governance in conceptualizing and institutionalizing a form of authority that could provide effective human rights protection when human rights violations by business enterprises fall beyond the jurisdiction of the state in which they are chartered, as is often the case with multinational corporations. ${ }^{14}$ In particular, there is widespread recognition of the

continuum, to the extent that (ii) and (iii) presuppose forms of validating the content and procedure of private ordering.

14. Daniel Augenstein \& David Kinley, When Human Rights 'Responsibilities' Become Duties: The Extra-territorial Obligations of States That Bind Corporations, in HUMAN RIGHTS OBLIGATIONS OF BUSINESS: BEYOND THE CORPORATE RESPONSIBILITY TO RESPECT?, 271-94 (Surya Deva \& David Bilchitz eds., 2013). 
urgency of reclaiming the notion of a common good, of which human rights are an integral part, as the yardstick by which to assess businesses and their operation. ${ }^{15}$ In the same way that the scope of business operations by multinational corporations is increasingly global, a social license to operate also demands that this license reflect a global common good. It would seem, therefore, that realizing this transformation demands overcoming the parochial distinction between inside and outside with a view to institutionalizing a properly global perspective on business and human rights. I argue, however, that following this line of reasoning would in fact entrench a key presupposition of the state-centered thinking about legal authority which animates the UNGPs, and which its critics had hoped to leave behind.

\section{GLOBalization: Two SENSEs OF THE InSIDE/OUTSIDE Distinction}

A range of scholars assume that, in contrast with territorial government, global governance calls for normative orders that organize themselves in such a way that the distinction between inside and outside loses all empirical and conceptual purchase. This distinction, like the distinction between the domestic and the foreign, is a merely contingent feature of some legal orders, not a feature that is constitutive for legal orders in general. These scholars seek to capture this spatial transformation with references to a "global perspective," the global "scale" of law, "supra-territoriality," "deterritorialization," "delocalization," "spaces of flows," and other such formulations. ${ }^{16}$ This spatial transformation goes hand in hand with the emergence of "overlapping" claims to legal authority, such that the state can no longer claim exclusive and sovereign authority over the population located in its territory. Accordingly, so the story goes, economic globalization demands abandoning the assumption that spatial inclusion and exclusion are necessary ingredients of legal order. On this view, economic globalization cuts the necessary link between legal authority and place, hence between legal authority and inclusion/exclusion, at least to the extent that this is a spatial distinction.

This story about the spatial transformation wrought by economic globalization is cause for celebration among the latter's defenders and

15. See generally David Kinley, CIVILISING Globalisation: Human RightS AND the GLOBAL ECONOMY (2009).

16. William TWINING, GENERAL JURISPRUdENCE: UNDERSTANDING LAW FROM A Global Perspective (2009); Boaventura de Sousa Santos, Towards a New Legal COMMON SENSE (second ed. 2002); GLOBAL LAW Without a STATE (Gunther Teubner ed., 1997); MANUEl CASTElls, The Rise of THE NETwORK Society (second ed. 2010). 
for much handwringing among its detractors. Either way, it is the basso continuo of contemporary legal and political theorizing about globalization. Whatever its merits, this story conceals an ambiguity that is of crucial importance to a proper understanding of legal authority in a global context: one must distinguish between the two forms of the inside/outside distinction. The first is the distinction between, respectively, the domestic and the foreign. Emergent global legal orders, such as the World Trade Organization (WTO), supersede the distinction between domestic and foreign legal spaces. There need be no quarrel here: this is undoubtedly a contingent feature of legal orders, as a range of contemporary theorists have pointed out. ${ }^{17}$ But there is a second form of the inside/outside distinction that has largely escaped the attention of the legal doctrine and theory but that is of decisive importance to a viable account of globalization: the distinction between a legal collective's own space and strange spaces.

These two forms of the inside/outside distinction are not identical. Consider the WTO. Like a state, the WTO configures itself as a spatial unity, even if of a very different sort: as a global market. Unlike a state, however, the spatial unity of the WTO is irreducible to territoriality. Indeed, the WTO organizes itself as a unity of legal places-a global market-in a way that supersedes the domestic/foreign distinction associated with states, regional orders such as the European Union (EU), or even classical international law, to the extent that the latter regulates relations between states. Yet, this does not mean that the WTO has moved beyond the inside/outside distinction in the second sense noted above. Indeed, global activists continuously challenge the WTO as being highly exclusionary in its operation, inasmuch as the enactment of a world market marginalizes nonmarketized spaces as unimportant and irrelevant. ${ }^{18}$ Yet, these places shelter forms of behavior that contest the normative criteria governing how the WTO organizes itself as a global market. Think, for example, of direct action by India's Karnataka State Farmers' Association (KRRS) against measures of trade liberalization under the aegis of the WTO.19 By mobilizing to occupy and destroy fields of genetically modified organisms (GMOs) in the effort to preserve and revalorize "traditional" peasant ways of life, the KRRS's direct action intimates a place that is outside of the WTO, even though not in the sense of a "foreign" place.

17. See generally works by the authors found supra note 16 .

18. See, e.g., Main Issues, VIA CAMPESINA, http://viacampesina.org/en/index.php/mainissues-mainmenu-27 (last visited Nov. 1, 2015) (where the Via Campesina [International Peasant's Movement] identifies their main issues of concern, several of which fall under the aegis of the WTO).

19. Ruth Reitan, Global Activism 156-159 (2007). 
Instead, their direct action intimates a strange place, a place that, from the KRRS's perspective, resists normative integration into the differentiation and connection of places that the WTO calls its own space: a global market. ${ }^{20}$ This suggests that, in the very process of constituting itself from a first-person plural perspective as a "we," the WTO must organize itself as an inside, configuring the global market as its own space by excluding other kinds of places that it deems irrelevant and unimportant with a view to realizing its aim: fostering global trade between its members. These marginalized places are intimated in forms of behavior that contest, more or less radically, whether and how the WTO distinguishes and connects places within the unity of a global market.

International human rights regimes are no exception to this fundamental sense of the inside/outside distinction. While claims to universality are certainly raised on behalf of human rights, such claims are the object of more or less radical contestation in a variety of ways. This is not the place to discuss the arguments advanced by a range of anthropological studies that human rights demand a historically contingent set of preconditions that, even today, are contested by alternative normative frameworks for social life. ${ }^{21}$ But there are at least two arguments internal to the human rights discourse itself that show why positivizing these rights in a global legal order demands a spatial closure that separates the own from the strange. The first is that positivizing human rights in an international or even global legal order requires a determination of the concept of humanity for legal purposes; that is, a limitation of what is germane from a legal perspective as constituting the commonality of "our common humanity." This determination calls forth the possibility of irreducible conflict about what constitutes the humanity of human beings. Consider, for example, the human right to life in the context of abortion and euthanasia. If human rights are a privileged focus of what John Rawls calls an

20. This discussion was previously published in Hans Lindahl, Reply to Critics, 16 ETHICS \& POL. 1001, 1011 (University of Trieste, 2014), available at http://www.openstarts. units.it/dspace/handle/10077/10695.

21. A locus classicus, but by no means the only one, is Herskovits's rejection of "the applicability of any Declaration of Human Rights to mankind as a whole," in a submission to one of the commissions of the United Nations entrusted with establishing the theoretical foundations of an international declaration of human rights. Am. Anthropological Ass'n, Statement on Human Rights, 49 AM. ANTHRoPologist 539, 542 (1947) (drafted by Melville Herskovits). A particularly radical illustration of this strong form of normative contestation of human rights is, arguably, the Islamic State. See Graeme Wood, What ISIS Really Wants, THE ATLANTIC (March 2015), http://www.theatlantic.com/magazine/archive/2015/03/what-isis-really-wants/384980/. 
"overlapping consensus," 22 they are no less a privileged focus of what I would dub an "overlapping dissensus." The second argument goes to the heart of the debate about business and human rights. It is significant that constitutions, in the course of positivizing human rights as fundamental rights, also establish the possibility of limiting their scope with a view to balancing individual rights and the common good. Could it be otherwise within a global human rights regime, whatever its form, in which trade-offs will be required between individual rights and business operations, in light of what is deemed to be the appropriate contribution that businesses can make to the global good? Any such trade-off includes and excludes and is vulnerable to challenges that call into question the commonality of the spatial unity claimed for a global human rights regime under which businesses must operate. ${ }^{23}$ In short, both arguments show that it is necessary to give a content to what counts as the commonality of the common space claimed for a global regime of human rights. By determining the content of commonality in one way, hence not in others, a global collective oriented to protecting human rights opens itself up to the charge of having unjustifiably marginalized behavior that has no place in the global collective yet which raises a claim to a place of its own.

None of this is an argument against human rights or an argument against demanding that businesses comply with human rights law. I argue only that human rights regimes cannot deliver what they are usually expected to deliver when claims to universality are raised on their behalf: that they are applicable "everywhere," where "everywhere" means a spatial unity that is no longer organized as an inside vis-à-vis an outside. A claim to a global common good is precisely that: a defeasible claim, no less so when the commonality of a global good is fleshed out in terms of human rights.

These considerations suggest that, from the perspective of this fundamental form of the inside/outside distinction, it makes no sense to distinguish between "literal" and "metaphorical" forms of inclusion and exclusion. Rights and obligations are always emplaced rights and obligations, to the extent that they presuppose a reference to the putative spatial unity a legal collective calls its own. Likewise, the closure that gives rise to a spatial unity as an "inside" conditions the possibility of distinguishing between legal and illegal behavior, in the sense of behavior that is either emplaced or misplaced, that is, behavior that ought or ought not to take place-literally-in the space a collective

22. JoHN RAWLS, POLITICAL LibERALISM 133-34, 150-54 (expanded ed. 2005).

23. See generally DAVId KinleY, CIVILISING Globalisation: HUMAN RiGHTS AND the GLOBAL ECONOMY (2009) (providing a nuanced account of the role of businesses in economic globalization). 
calls its own. Conversely, that a collective claims a space as its own, by virtue of a closure that establishes it as a common space, is a claim to be empowered to establish what counts as emplaced and misplaced behavior within that space. If the distinction between legality and illegality, between emplacement and misplacement, depends on the closure of space into an inside, this spatial unity, and the rights and obligations that accrue to actors within it, can be contested from elsewhere. This "elsewhere" is comprised of places that have no place in that spatial unity yet are places with which rights and obligations are associated, which are in (sometimes radical) conflict with the rights and obligations included in the contested legal order. In contrast to emplacement/misplacement, what lies outside of a common space manifests itself as dis-placed behavior. This casts new light on the concept of legal space. In effect, legal space is not simply "geographical" space; it is a normatively charged space in the sense that the law organizes space by differentiating and connecting places as oughtplaces. ${ }^{24}$

Accordingly, economic globalization exposes the contingent spatiality of territorial government, to the extent that it organizes the inside/outside distinction in terms of the domestic and foreign places. A theory and practice of authority whereby multinational companies can be held accountable for human rights violations in the course of their global operations cannot continue to rely exclusively on the distinction between the domestic and the foreign. But this by no means justifies the further thesis that the distinction between own and strange places is also contingent. In this fundamental sense, the inside/outside distinction is a necessary feature of all legal orders, whatever their "scale" or content. Before proceeding to draw out the conceptual and institutional implications of this thesis for a credible social license to operate in a global context, I outline the concept of legal order which subtends this strong thesis about spatial closure.

\section{AUTHORITATIVE COLLECTIVE ACTION}

The concepts of authority and of the authoritative ordering of society appropriate to making sense of a social license to operate, whether in a national or a global context, can best be elucidated in terms of what I will call authoritative collective action (ACA). I argue

24. For a range of examples of this general feature of legal order, including nomadic communities, Roman law, international law, multinationals, lex mercatoria, and cyberlaw, see HANS LINDAHL, FAULT LiNES of GLOBALIZATION: LEGAL ORDER AND THE POLITICS OF A-LEGALITY 44-76 (Martin Loughlin et al. eds., 2013). 
that this concept of legal order is sufficiently general to encompass a wide variety of legal orders while also sufficiently discriminating to allow for highlighting significant differences between a variety of such orders. I will parse this concept into its two components: collective action (the genus) and authority (the species).

Legal orders are a species of collective action, a form of action which Margaret Gilbert succinctly captures with the integrative expression "we together," in contrast to the aggregative or summative expression "we each." 25 A number of features of collective action deserve closer attention. First, legal obligations and sanctions are a species of the entitlements and rebukes that emerge between participant agents in the course of collective action-“"relational" or "directed" obligations, to adopt Gilbert's (and H.L.A. Hart's) vocabulary. ${ }^{26}$ Second, the nature and scope of legally relevant behavior, as well as the rights and obligations that accrue to participant agents, are internally related to the normative point of joint action: that which our joint act ought to be about. Third, collective action and its normative point can be nested in higher-order-hence more general-forms of collective action and their respective normative points, in which case nested collective action must be rendered consistent with the higher-order normative point. So, for example, a franchise contract might be nested in the more encompassing form of collective action called a state. Fourth, joint action deploys a four-dimensional order: spatial, temporal, subjective, and material. Depending on what we are doing together, collective action selects and connects places (e.g., the places that make up a global market), times (e.g., the proper sequence of actions in global trade), subjects (e.g., the different kinds of persons required to engage in global trade), and act-contents (e.g., the different activities involved in global trade). Fifth, the point of joint action determines what is relevant and important to joint action, hence what kinds of places, times, subjectivities, and act-contents are relevant and important to realizing the normative point of joint action, such that other possible combinations are marginalized as irrelevant. In other words, collective action in general, and legal collective action in particular, cannot include certain spaces, times, subjects, and act-contents without also excluding other spaces, times, etc., as irrelevant and unimportant. Here is the answer to why social groups in general, and legal groups in particular, cannot but organize themselves as an inside vis-à-vis an outside. For what I have called a "strange outside" is nothing other than

25. Margaret Gilbert, ON SocIal FaCTS 168 (2d ed. 1992).

26. Margaret Gilbert, A Theory of Political Obligation 40, 153-61 (2006) (drawing explicitly on Hart's notion of relational obligations from his famous essay, H.L.A. Hart, Are There Any Natural Rights?, 64 PHIL. REv. 175 (1955)). 
the contestation of what counts as important and relevant with regard to the commonality of a space, issuing from the domain of what has been rendered irrelevant and unimportant. Finally, social orders are mutable, which means that the rules that establish who ought to do what, where, and when are a default setting of the normative point of (nested) joint action.

Significantly, what we ought to do together-the normative point of joint action under law-may itself be open to discussion and conflict, as is the case with other forms of social groups. This follows from the fact that there can be no inclusion in collective action that is not also accompanied by exclusion. However, and in contrast to other social groups, legal orders involve authorities that, acting on behalf of the group, regulate and uphold participant agency with a view to realizing the normative point of joint action.

The specific difference of legal collectives with respect to other kinds of collectives turns on how questions about joint action are dealt with. We are witness to a legal collective when certain questions are not left over to the collective's members to decide for themselves: questions about the normative point of joint action; about the rights, obligations, entitlements, and responsibilities that arise in the light of that normative point; about the consistency of participatory agency with regard to the normative point of joint action; and, finally, about the consequences that follow from inconsistency with that normative point. In a legal order, these and related questions, especially if they are the source of conflict, are settled by authorities who claim to act on behalf of the whole, such that dissenters and reprobates are bound by that decision. All of this makes for a relatively robust identity over time of the legal group.

This is, to be sure, a strictly functional account of authority: an account that tells us what authorities do. Notice, however, that this account already paves the way for a normative conception of authority, to the extent that authorities claim to act on behalf of the whole. Indeed, if the authoritativeness of regulation necessarily involves a claim to commonality, then this claim can be contested by challenging who and what is to be included in and excluded from the whole. In short, the normativity of authority comes to the fore in the fact that the regulation of joint action is a response to the practical question that confronts a collective at every turn: What ought our joint action to be about? I will return to this shortly.

In the course of regulating group action, legal authorities articulate general and particular rules that are the default setting of the normative point of joint action. The concept of rules, as $I$ use it, accommodates a wide range of normative standards. It obviously 
includes legislation, administrative acts, and judicial rulings, no less than international treaties, as one would expect in territorial government. But it also includes, for example, model contracts as deployed in certain sectors of lex mercatoria, the regulations drawn up by international accounting organizations, technical regulations and standards, all of which belong to the domain of global governance. ${ }^{27}$ In short, regulation, as I construe it, encompasses both "hard" law and "soft" law, where the latter refers to "statements of principles, guidelines, understandings, model laws and codes and declarations that ... are 'neither strictly binding norms of law, nor completely irrelevant political maxims."'28

If this is what the regulation of joint action by authorities is about, legal orders also typically involve authorities who uphold joint action, meaning that they not only rebuke miscreants for breaching their obligations under collective action but also take steps to ensure that participating agents comply with joint action and its normative point. I define compliance broadly, including but not limited to physical coercion. It encompasses a wide range of means that authorities can marshal against those who breach directed or relational obligations with a view to bringing them into line with collective action and its normative point.

This account of legal order is very broad. In particular, the ACA model of legal order cuts across the distinction between territorial government and global governance. ACA, as sketched out above, accommodates the emergence of a slew of transnational or even global, private, self-regulatory groups, as well as hybrid public-private forms of governance. In particular, the mutually exclusive territoriality of states, which is the point of departure of territorial human rights government, is but a limiting case of a broader spectrum of possibilities that includes the functional, regional, and global legal orders that emerge from the uncoupling of law and state. Finally, the ACA model of law allows for variable levels of robustness with respect to the identity of legal collectives.

Notice that the ACA model of law includes multinational corporations (MNCs). Certainly, MNCs are nested forms of collective action to the extent that they are chartered in a given state and subject

27. Colin Scott, Regulating Global Regimes, in HANDBOOK ON THE POLITICS OF REGULATION 563-575 (David Levi-Faur ed., 2011).

28. A. Claire Cutler, Virgina Haufler \& Tony Porter, The Contours and Significance of Private Authority in International Affairs, in PRIVATE AUTHORITY AND INTERNATIONAL AFFAIRS 333, 367-68 (A. Claire Cutler, Virgina Haufler \& Tony Porter eds., 1999). 
to the laws of the states in which they operate. ${ }^{29}$ But this is not the whole story. Given the global scope of their operations, MNCs can take up a first-person plural perspective that is irreducible to their nesting in the states in which they operate. This first-person plural perspective is often highly effective, even when the MNC's internal regulations violate state law. For example, it is not surprising that the resistance of the Ogoni people to the destruction of their lands by Shell's operations in the Niger Delta was leveled against Shell itself and not merely against the state of Nigeria. ${ }^{30}$ Regardless of the role played by the Nigerian government in repressing Ogoni resistance, it is clear that Shell exercised and continues to exercise a level of autonomous decision making in the pursuit of its global interests in a way that Nigeria cannot adequately authorize or contain by way of legislation enacted from its state-centered first-person plural perspective. ${ }^{31}$

There are two general implications that follow from these considerations. The first is that if, as I argue, globally operating businesses are distinct legal orders, then, conceptually speaking, there is no reason that their global operations should lie beyond the domain of law, as assumed by the cardinal distinction between state and business. Returning to Part I, the entrenchment of state-centered thinking about law reflected in the opposition between state and business, and, subsequently, between businesses' compliance with applicable laws and respect for human rights, rests on a reductive understanding of the concept of legal order. As a result, the ACA model of law offers a strong conceptual defense of why MNCs can be treated as subjects falling directly under the rule of international law, on par with states. Both states and globally operating businesses are legal orders in their own right. From the first-person plural perspective of authoritatively mediated collective action, nothing justifies separating a state's obligation to uphold human rights, as per the first pillar of the UNGPs,

29. See here the first pillar of the UNGPs, the first foundational principle of which lays down that "[s]tates must protect against human rights abuse within their territory and/or jurisdiction by third parties, including business enterprises. This requires taking appropriate steps to prevent, investigate, punish and redress such abuse through effective policies, legislation, regulations and adjudication." U.N. Human Rights Office of the High Commissioner, supra note 1 , at 3 .

30. See, for example, Saro-Wiwa's speech during his trial for incitement to murder. Ken Saro-Wiwa, Ken Saro-Wiwa's Final Address to the Military-Appointed Tribunal, 11 EARTH ISLAND J. 25 (1995).

31. I draw here on the excellent text by Daniel Augenstein, Paradise Lost: Sovereign State Interest, Global Resource Exploitation and the Politics of Human Rights (forthcoming; on file with the author); see also Michael Watts, Resource Curse? Governmentality, Oil and Power in the Niger Delta, Nigeria, 9 GEOPOLITICS 50-80 (2004). 
from a business's duty to respect human rights, as per the second pillar. ${ }^{32}$

The second implication follows from the fact that, in the course of their global operations, MNCs respond to the key practical question confronting collectives-what ought our joint action be about?-in a way that eludes nesting within the normative criteria of inclusion and exclusion posited by state legal orders. This feature of $\mathrm{MNCs}$ is precisely what the second pillar of UNGPs attempts to address in terms of the appeal to "respect human rights," where respect, according to the UNGPs, does not have the status of a legal obligation. ${ }^{33}$ This exposes the core problem that remains unaddressed by the second pillar of the UNGPs as a result of its distinction between state law and non-law. The recurrent tensions between shareholder and stakeholder interests; between profits for shareholders and the social costs generated by MNC operations; between the pursuit of profit over time and the sustainability of life for this and future generations of sentient beings all attest to the need for nesting collective action by MNCs within a more encompassing social group commensurate with the global scope of their operations. Only in this way can MNCs lay claim, normatively speaking, to being not only an instance of authorized collective action but also of authoritative collective action in the course of their global operations. Accordingly, the ACA model of law offers a strong normative defense of why MNCs should be treated as subjects falling directly under international law, in particular as subjects of international human rights law.

\section{A SOCIAL LiCENSE TO OPERATE IN A GLOBAL CONTEXT}

I began with the question of how to make sense of, and lend traction to, the preposition "of" in the claim that "business enterprises [are] specialized organs of society." 34 What credible sense can be given to the notion of an authorization to businesses and their operations such that society can view businesses as its own organs and their functions and activities as its own functions and activities? The ACA model of legal order provides a framework by which to assess what could be a credible

32. In contrast to the first foundational principle of the first pillar (see supra note 29), Foundational Principle 11, pursuant to the second pillar, holds that " $[\mathrm{b}]$ usiness enterprises should respect human rights. This means that they should avoid infringing on the human rights of others and should address adverse human rights impacts with which they are involved." See U.N. Human Rights Office of the High Commissioner, supra note 1 , at 13 .

33. See id.

34. See supra text accompanying note 1. 
interpretation of a social license to operate in a global context and whether corporate "respect for human rights," as laid out in the UNGPs, is consistent with such an interpretation. While the answer to this question is relatively straightforward in the context of territorial government, it is much less so in the context of global governance, in which the territorial forms of the public/private and inside/outside distinctions have lost empirical purchase.

The clue to a general answer is already enclosed in the question itself. For at issue is not society as a more or less amorphous and anonymous mass of individuals; at issue is the emergence of the firstperson plural perspective of a "we" in joint action. If there is to be a social license to operate, then the referent of "social" is not "society"; it has to be a social group-a plural subject. This means that a social license to operate demands that it be possible to view businesses as actors participating in collective action and their acts as participant acts from the perspective of a "we." In other words, to say that businesses are authorized to act is to acknowledge that the members of the group can view business operations as part and parcel of what we, the social group, are doing together with a view to realizing the normative point of our joint action. To the extent that a business is a social participant because it contributes to realizing what the group's action is about, the social group can call the business's operations its own. What is required is to nest the global operations of MNCs in higher-order collective action. Such nesting is possible, or so the ACA model of law argues, because $\mathrm{MNCs}$, as distinctive legal orders irreducible to the states in which they operate, are distinct legal subjects capable of falling under the aegis of international law.

What is at stake here is not primarily a legal sense of ownership, for example, a property right. Instead, what is primarily at stake is the notion of ownership implied in a reflexive form of collective identity and identification. By these lights, the fundamental form of ownership evoked by referring to a business's operations as "our own" is the notion of empowerment. To authorize is to empower, to open up a repertoire of practical possibilities concerning who ought to do what, where, and when with a view to realizing the point of joint action. Property rights are forms of legal empowerment and so also the right to contract. Both are particular legal manifestations of the reflexive form of collective identification presupposed in calling an actor or an act our own; that is, an actor or an act that we, as a social group, have authorized or empowered. Likewise, to disallow or to disqualify an act, to deny it the character of a participating act or actor, is to disown it, to gainsay that it fulfills our expectations of what our joint action is about. 
The emergence of the first-person plural perspective of a social group, therefore, is the general condition that must be met such that one can meaningfully speak of a social license to operate, whether in the context of territorial government or of global governance. This condition also explains why the public/private and inside/outside distinctions remain the indispensable preconditions of a social license to operate in the context of global governance.

Taking the former distinction first, the claim to a public or common good is built into the very concept of ACA, in particular into the properly normative notion of authority presupposed in its functional interpretation as regulating and upholding collective action. Not only are participating agents to act together; their collective action is also premised on what are deemed to be mutual expectations about what their joint action ought to be about: the normative point of their action. The reference to mutual expectations, hence the claim to generality made on behalf of legality, is crucial because the UNGPs' reference to "social expectations" is incapable of making sense of the publicness proper to ACA, absent which all talk of authorizing or licensing businesses to operate is disingenuous. As David Bilchitz points out, "social expectations" is a normatively underdetermined concept because members of a society can entertain very different, even conflicting, expectations of corporate behavior. ${ }^{35}$ His objection can be recast, from the perspective of the ACA model of law, in the following way: social expectations do not give rise to directed or relational obligations, without which there can be no meaningful talk of a social license to operate. No commonality, no publicness, follows from the invocation of social expectations; the notion takes us no further than an aggregative interpretation of the pronoun "we" as "we each." It is this methodological individualism that animates attempts to privatize and marketize public authority. Commonality only comes into the picture with claims to reciprocity, hence with references to a normative point that is deemed to determine what binds us together as a social group: "we, together." But the emergence of a social group, and of the relational or directed obligations on which it thrives, requires a closure that gives rise to a bounded common good. No less than in a state-centered context, in a global context a social license to operate involves a determinate legal default setting with respect to the key practical question confronting the members of a collective: what ought our joint action be about? What I call the "nesting" of MNCs in a global social

35. See David Bilchitz, A Chasm Between 'Is' and 'Ought? A Critique of the Normative Foundations of the SRSG's Framework and the Guiding Principles, in HUMAN RIGHTS OBLIGATIONS OF BusINESS: BEYOND THE CORPORATE RESPONSIBILITY TO RESPECT? 107, 119-23 (Surya Deva \& David Bilchitz eds., 2013). 
group is nothing other than the process by which they are empowered to act in accordance with the default setting of that group's normative point.

If, as I argue, there can be no ACA without a bounded common good, it becomes clear why a social license to operate in a global context cannot do without the spatial distinction between inside and outside and why the way in which a global ACA would draw this distinction is vulnerable to challenge. Indeed, the emergence of the first-person plural perspective of a social group requires a determination of our common or joint good. This demands a spatial closure that includes and excludes. Although the emergence of a global ACA does not organize itself spatially as the distinction between the domestic and the foreign, it could not distinguish between behavior that is legal or illegal, emplaced or misplaced, absent a closure that marks off an inside as the space a collective deems its own, hence a space that orders behavior in terms of whether it lives up to or is in breach of inter alia human rights obligations. As exclusion, the closure that inaugurates the first-person plural perspective of a global ACA relegates everything that is beyond the pale of joint action and its normative point to the residual domain of the unordered. Accordingly, the emergence of a common space, a global space we can call our own because it is the spatial unity that differentiates and interconnects the kinds of places that are relevant and important to realizing the point of our joint action, goes hand in hand with the marginalization of places that are deemed irrelevant and unimportant. The latter can manifest themselves as an outside, intimating another way of organizing space as a common space that calls for realization through behavior that challenges the commonality claimed for what a global collective calls its own legal space. This would be the case, for example, for behavior that contests how a global ACA determines the content of human rights with respect to business operations.

In short, the emergence of a global first-person plural perspective demands a collective self-emplacement by way of a spatial inclusion and exclusion. And this collective self-emplacement is the condition required for authorization as a spatial authorization, a where-empowerment, such that acts and actors can appear as emplaced or misplaced, hence as allowed or disallowed, against the backdrop of an outside that manifests itself in acts that appear as dis-placed, as dis-empowered.

Accordingly, the twofold condition for authority in territorial government continues to operate, albeit in a transformed manner, as the twofold condition for a viable concept of legal authority in global governance. Indeed, a social license to operate presupposes that in global governance, publicness, as the common good, is conditioned by a 
spatial closure: a common space. Conversely, a common space, in the sense of global governance, is conditioned by a determinate common or public good. Extending a license to businesses to operate globally, which means authorizing their acts to the extent that they are in accordance with the common good, presupposes a closure that splits the face of the earth into an inside and an outside in the sense of the own and the strange, and vice versa. Contrary to what the literature on global governance would have us believe, the problem raised by business and human rights is not to reconstruct authority beyond the inside/outside divide. It is precisely the opposite: how to bring about a spatial closure that allows for opening up the world as a common space organized according to the distinction between emplacement and misplacement, legality and illegality, such that human rights can take hold as directed or relational obligations.

To summarize, the connection between a bounded common good and a bounded common place is both the condition and the object of authority in global governance. Because the disparateness of "social expectations" shows that every default setting of the common good is deeply contentious, there can be no credible social license to operate in a global context absent authorities that uphold and regulate joint action with respect to what counts as a global collective's bounded common good and as its bounded common place. If this authoritative feature of ACA is lacking, the preposition "of" in the UNGPs inaugural claim that "businesses [are] specialized organs of society" is empty of content. Yet, this is the very feature that the UNGPs preclude when proclaiming that the corporate responsibility to respect human rights does not create a legal obligation in its own right, in the broad sense of the expression apposite to $\mathrm{ACA}$ : an authoritatively mediated relational or directed obligation.

This crucial feature of a credible social license to operate in a global context is brought home if we contrast the UNGPs to the OECD's Guidelines for Multinational Enterprises (GMEs). The GMEs are "recommendations addressed by governments to multinational enterprises operating in or from adhering countries. They provide nonbinding principles and standards for responsible business conduct in a global context consistent with applicable laws and internationally recognised standards." ${ }^{6}$ Crucially, the National Contact Points (NCPs), established by the governments who have adhered to the GMEs, "assist enterprises and their stakeholders to take appropriate measures to further the implementation of the Guidelines. They also provide a mediation and conciliation platform for resolving practical issues that

36. OECD, OECD GUIDELINES FOR MULTINATIONAL ENTERPRISES 3 (2011). 
may arise." 37 The aim of the NCPs is to "further the effectiveness of the GMEs,"38 to which end the GMEs put in place a procedure for implementation that concludes, in the case of continued disagreement between the parties involved, with a statement that lays out the issue at hand, why the NCP decided to examine it, the procedure used, and recommendations to the parties on the implementation of the GMEs. The statement is made public. ${ }^{39}$

We have here, I submit, a case of emergent ACA in the framework of global governance. There is collective action in which multinational enterprises are viewed as participating agents engaged in operations that are authorized to the extent that they contribute to realizing the normative point of joint action; there are authorities who are entrusted with regulating the normative point of joint action, both by way of general and particular rules, albeit in the form of soft law; and there are mechanisms in place oriented to pushing parties in breach of the GMEs to comply with them. In a careful and innovative study of DAS Air and Afrimex, two cases brought before the United Kingdom NCP by civilsociety actors, Larry Catá Backer shows how, in both cases, the NCP was able to regulate behavior effectively through mechanisms of soft rather than hard law: "The technical monopoly power of the state over law was not affected by regulatory systems that do not bind in law and could thus have an equivalent effect, at least as far as the entity subject to NCP proceedings is concerned." 40 In fact, these two cases point to an autonomous "normative system in the making," and mark "another step in the reconstitution of supranational governance and the allocation of governance rights and obligations." 41

While Catá Backer follows the traditional distinction between hard and soft law in this passage, what interests me is that his analysis of these two cases offers a concrete illustration of the general structure of ACA, a structure that cuts across the distinctions between territorial government and global governance and between hard and soft law, while also showing the core features of authority that must be retained in the latter, if we are at all to make credible sense of a social license to operate in a global context. On one hand, there are authorities that regulate and uphold the normative point of joint action, even if in ways that are different from those marshaled by territorial states. On the

37. Id.

38. Id. at 68,71

39. Id. at $72-74$.

40. Larry Catá Backer, Small Steps Towards an Autonomous Transnational Legal System for the Regulation of Multinational Corporations, 10 MELB. J. INT'L L. 258, 288 (2009).

41. Id. at 266 . 
other hand, there are actors who can raise allegations of breaches of the standards contained in the GMEs. Through their interventions, the NCPs and the organizations of civil society effectively claim to represent a global plural subject; they take up the first-person plural perspective of a global "we" when demanding that multinational enterprises live up to the standards that are the default setting of that social group's normative point.

This representational claim aims, on one hand, to reconstitute the public/private divide, insofar as acts by multinational enterprises are deemed to be authorized only to the extent that they can be viewed as concretizations of a bounded-albeit global-common good, as laid down in the regulations of the GMEs. In fact, it would be more adequate to say that these representational claims seek to reconstitute the public/private distinction as public. On the other hand, their interventions aim to reconstitute the inside/outside distinction by way of a bounded-albeit global-common space, a space that is our own to the extent that "we," the global community they seek to represent in the very process of creating it, claim to be entitled to establish what ought to take place therein by defining behavior that is emplaced or misplaced to the extent that it either lives up to or is in breach of human rights obligations. If the allegations of breaches of the GMEs leveled by civil society against multinational enterprises contest what has been included and what has been excluded from the common space of the global GME community, the recommendations by the NCPs and by the Investment Committee of the GMEs contribute to recalibrating the bounded common good of that collective, as laid down in the regulations that constitute its default setting. ${ }^{42}$

\section{CONCLUSION}

The ACA model of law suggests that this is one of the ways, no doubt still very modest, by which it might begin to become credible to assert, in a global context, that businesses are specialized organs of society and that a corporate responsibility to respect human rights is an authoritatively mediated relational or directed obligation. Against the entrenchment of state-centered thinking of law that follows from opposing states to businesses, and then opposing a business's obligation to comply with applicable law and social expectations that it respect human rights, the ACA model of law unifies what the UNGPs separate.

42. The Investment Committee operates, generally speaking, as a forum for consultations about the GMEs, including their clarification, with a view to ensuring the effective functioning thereof. See OECD, supra note 36, at 68-69. 
ACA argues, first, that businesses are no less legal orders in their own right than states; and second, that because the domain of legal obligations is coextensive with ACA, all activities of globally operating businesses are subject to international human rights law. To move beyond state-centered thinking about law, in response to violations of human rights by globally operating businesses, is to acknowledge that there is one pillar that embraces states and businesses: the legal obligation to comply with international human rights law. 